\title{
Mycofloristic findings in Halikko, SW Finland
}

\author{
Ant $i$ Nyman
}

In the study by Kallio (1963) on the mycoflora of the Finnish oak-zone, the fungi of Halikko (V) are frequently mentioned; three of his research points are situated in that very parish. After the publication of that study, I have observed these fungi on many excursions, most of which were made to Halikko. Some or those observations are reported here.

Leccinum griseum (Quel.) Sing.

The occurrence of this species in Finland has been thoroughly discussed by Kallio (op. c., pp. 59 $-60)$, who concluded that the only certain localities of the species in Finland are Espoo. Bromarv and Turku (Katariinanlaakso). In the autumn of 1965 the species was found in the following new places: Turku, Ruissalo; Halikko, Vuorentaka (Vaisakko), Keravuori, Pappila, Märy (Pihko) and Tavola; Karjalohja, Piipola (Heponiemi). Regarding the localities at Halikko, Vaisakko and Pihko are the points 21 and 22 in Kallio's study (op. c., Abb. 1), Tavola is immediately to the south of point 23; the localities at Keravuori and Pappila are hazel groves situated at the base of cliffs 600 metres from one another. The locality at Heponiemi in Karjalohja is an oak-hazel grove situated on a southwest slope at the edge of a field. The fungus always grew on the bare soil under the hazel trees. Oaks were usually also nearby, but in the woods at Keravuori and Pappila there were no oaks at all, and at the latter place, the vicinity of one of the sites had only Prunus padus L. and Sorbus aucuparia L. in addition to hazel. The species was found during the period Aug. 24-Sept. 26, 1965, and at Vaisakko, Pappila and Pihko in Halikko Aug. 18-22. 1966, too. The fungal occurrences were usually small, comprising $1-5$ fruit bodies. The species was most abundant in the woods at Pappila in Halikko, where about twenty fruit bodies were discovered in the first week of September, 1965.

Since Leccinum griseum and L. scabrum (Bull. ex Fr.) S. F. Gray closely resemble one another, all of the determinations included not only the examination of macroscopic features - e.g. the darkening of the cut surface of the former species - but also microscopic characters, notably the structure of superficial layer of the cap (cf. Kallio, op.c.). The absence of pigment in the sphaerocysts, mentioned by Kallio, was a valid feature also in these examinations, with the exception of one young fruit body, which was darker in colour than the others. The sphaerocysts in this particular body definitely contained pigment. On the basis of 200 measurements made on the specimens collected from Pappila, Halikko, the size of the spores was $16.54 \pm 0.004 \times 5.45 \pm 0.005 \mu$.

Lepiota seminuda (Lasch) Gill.

Cap 0.6-1.5 cm, pale yellow, brownish toward the centre, fine grained, remnants of veil at the margins. Gills white. Stalk 20-30x $1 \mathrm{~mm}$, upper part pale yellow, lower part reddish brown. Superficial cells of the cap globose, diam. ca. $15-36 \mu$. Size of spores $4.46 \pm 0.009 \times 2.62 \pm 0.002 \mu$ ( 100 measurements). Found on October 2-9, 1965 and September 17, 1966 at Halikko, Vaisakko. The locality was a narrow, very shady grove near the seashore, bordered on its west side by a steep cliff and on the east by a field. The trees growing here were Picea abies (L.) H. Karst., Quercus robur L., Corylus avellana L., Populus tremula L., Salix caprea L. and Prunus padus L.; among the shrubs, Lonicera xylosteum $\mathrm{L}$. was growing in the immediate vicinity. Other floristic features of the grove are described by Kallio (op.c., p. 40). Owing to its shadiness and the nearby cliff, the soil moisture conditions of this place evidently are favourable even in dry summers.

MaLmStröm (1943) reported finding the species in western Uusimaa: »N. Ekenäs, Tvärminneön 13. 9. 1936 ett icke fullt utvecklat ex." (a specimen not completely fully developed). The following samples are in HMF: N. Helsinki, Botanical Garden 19.9. 1936 R. Frey; N. Kauniainen, at the cottage of Prof. Nyberg 3.9.-8. 10. 1938, W. Nyberg. SarulMANN (1963) mentions finding two fruit bodies of the species at Fagervik in Inkoo in 1960. All the known localities are thus along the southern coast, so that the species appears to be a southern, chiefly oak-zone species in this country. A partial reason for the scarcity of known localities, however, may be the small size of both the fruit bodies and the occurrences.

Melanophyllum eyrei (Mass.) Sing.

Syn. Lepiota eyrei (Mass.) Lange.

Two fruit bodies of this species were found growing together at Vaisakko in Halikko on October 2,1965 . The fungus was growing on bare ground only a few metres from the above-described occurrence of Lepiota seminuda. One of the fruit bodies was partially rotted but the other was in very good 
condition; its cap was $2 \mathrm{~cm}$ in diameter, creamcoloured on the margins, sligthly more brownish toward the centre, granular, with remnants of veil at the margins; the light blue-green colour of the gills was very conspicuous; stalk $55 \times 3 \mathrm{~mm}$, upper part granular, lower part smooth and brownish. Spores $2.85 \pm 0.005 \times 4.46 \pm 0.004 \mu$ (100 measurements).

As far as is known, the species has not been encountered before in Finland. According to LANGE (1935) the species is rare in Denmark.

Melanophyllum echinatum (Roth ex Fr.) Singer.

Syn.: Lepiota haematosperma (Bull.) Boud., L. echinata (Roth) Quenl., M. Canali Vel.

This species likewise was growing at the same site in Vaisakko, Halikko, where the previously mentioned $M$. eyrei and Lepiota seminuda were found. Of these three species, which also systematically are closely related, $M$. echinatum was the most abundant; during the period Sept. 22-Oct. 7, 1965 more than a dozen separately growing fruit bodies were discovered, and on Sept. 10-17, 1966 less than a dozen. Especially as regards the appearance of their stalk, they resembled very closely Lepiota haematosperma forma gracilis described by LANGE (1935). Specifically, the ring was either lacking completely or was much less distinct than the one of the main form shown in Tab. $14 \mathrm{D}$; furthermore, the stalk was nearly smooth, with only a slight amount of light powder. However, the diameter of the cap, 10-21 mm, does not agree well with that of f. gracilis described dy LANGE, which had a diametre of approximately $1 \mathrm{~cm}$. The stalk of the specimens collected at Halikko had dimensions of $35-55 \times 2 \mathrm{~mm}$. Size of spores $6.10 \pm 0.000 \times 3.26 \pm$ $0.004 \mu$. (200 measurements). The globose cells of the superficial layer of the cap had a diameter of about $24-42 u$.

The only known sample of this species hitherto found in Finland is in $\mathrm{H}$; the fungi in this sample were collected in the glasshouse of the Helsinki Botanical Garden (1950, N. Malmström).

Pholiota albocrenulata (Peck) Sacc.

This species was known up to the year 1934 only in North America, where it was first described by PECK in 1873 on the basis of fruit bodies found in the Adirondack mountains of New York. He considered the species to be very rare. Overholts (1927) lists five additional localities, all being in the eastern parts of the U.S.A. According to KaUfFMAN (1918), the species is quite common in certain places in northern Michigan but is rare in the southern parts of the state. In Europe the species was found in 1934 (Pouchet 1935) in the department of Rhone in France. Two years later, one single fruit body was encountered in the Carpathians of Czechoslovakia (Pilét 1936). In $1964 \mathrm{Ph}$. albocrenulata was found in Lithuania (Mazelartis, Gricrus \& URBONAS 1965).

On September 27, 1964 two strange-looking fruit

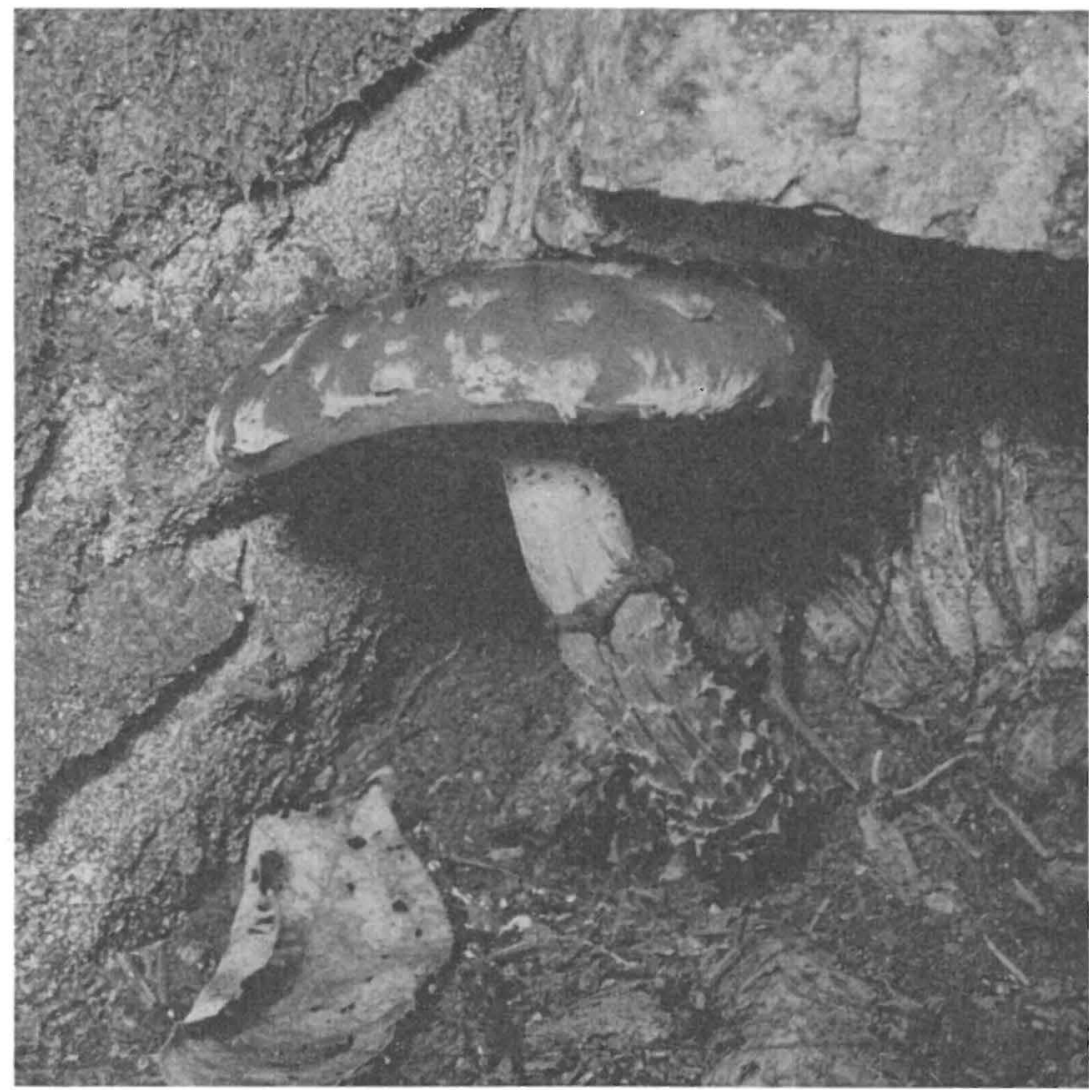

Fig. 1. - Pholiota albocrenulata (Peck) Sacc. 


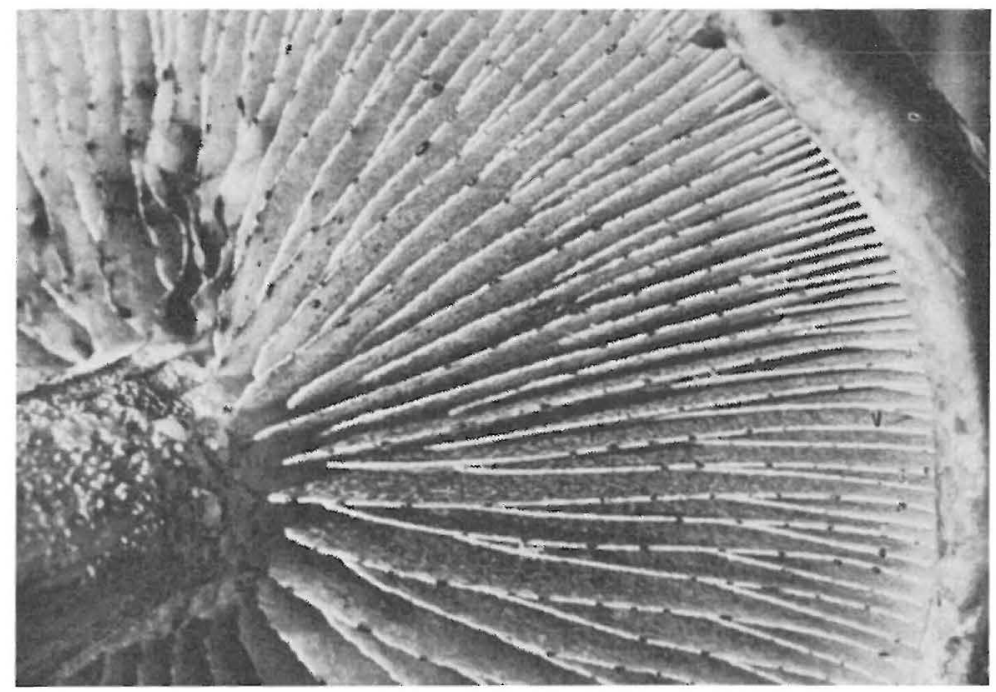

Fig. 2. - Gills of Pholiota albocrenulata (Peck) Sacc.

bodies were found at the base of a large Populus tremula in the Vaisakko woods in Halikko at the same place which is described above in connexion with Lepiota seminuda. The species, however, was not identified. In the following autumn, I had the fortunate opportunity to act as guide for Dr. Hans Haas (Stuttgart) on an excursion in the same area. At the base of the same tree we again discovered two fruit bodies, which Dr. Haas identified as Pholiota albocrenulata. (Fig. 1) On the same excursion Miss Raili Suominen collected one fruit body of the same species which had been growing on a stump apparently a few dozen metres distand from the first-mentioned site. During the period August 26, - October 2, 1965, a total of ten fruit bodies was found on this asp. In 1966, Aug. 20. Sept. 6. three fruit bodies were grown again on the same tree. The fruit bodies emerged from the base of the aspen at the ground level or from holes in the roots; in addition, a group of three fruit bodies grew on the stub of a branch at a height of nearly 3 metres. Another parasitic fungi growing on the same tree was Phellinus igniarius L. Just $1-15$ metres from this tree, other fungi which are rare in Finland were also growing: Xerocomus chrysenteron (Bull. ex Fr.) Quel., Helvella crispa Scop., and the above-bescribed Lepiota seminuda and Melanophyllum species.

Since I have not seen reports of this species in Scandinavian mycological literature, I shall give below a description of the external appearance of the fungus on the basis of the fruit bodies collected.

Cap 5-11 cm. initially conical, later convex, becoming flatter, margins turned sharply inward central part elevated; colour brownish with a tinge of purble; very viscous; surface covered with a few usually triangular, $5-7 \mathrm{~mm}$ wide soft scales, which in dry weather are light tan in colour, distinctly lighter than the cap. Remnants of the veil are usually to be seen on the margins of the cap; the veil is thick, pulpy, light tan.
Gills (Fig. 2) initially greyish white, later becoming more and more spotted with brown or evenly brown in colour, 7-10 $\mathrm{mm}$ wide near the stalk. Edges of gills white, serrate, with drops of liquid; along these edges are rows of white nodules produced by basidium-resembling sterile cells which have coalesced into a fan-like cluster (PrLát 1936, Fig. 3). No pleurocystids are present.

Stalk $7-12 \mathrm{~cm}$ long, 9-15 $\mathrm{mm}$ thick, becoming slightly thicker towward the base, cylindrical; below the ring completely covered by brown, spreading scales, unevenly brown; above the ring white, containing liquid drops but no scales. The ring most often indistinct, but sometimes, however, very clear (Fig. 1), hanging, dark brown, finely stranded.

Spores brown, smooth, almond-shaped, dimensions, $\quad 12.57 \pm 0.003 \times 6.78 \pm 0.001 \mu \quad(200$ measurements).

The above macroscopic characters, such as the form and colour of the cap, its viscosity and the nature of the scales, the distinctive structure of the gills, as well as the special features of the stalk and ring, agree completely with the descriptions given by Pouchet and PILÁt of European samples of $\mathrm{Ph}$. albocrenulata and also with the description of Christensen (1955). Moreover, there are apparently no significant differences as regards the size of the spores. The figures mentioned by Pouchet are slightly smaller, $10-11.5$. (-13) x 5.5-6 (-6.5) $\mu$, while those reported by PiLÁt were $10-12 \times 6-7$ and by PECK $10-12.5 \times 6-7.5$.

PILÁt (op.c.) mentioned finding $P h$. albocrenulata growing on the trunk of a living Abies alba in the Carpathians, while the host reported by Pouchet was Populus canadensis. In America the most common host plant appears to be Acer saccaratum Marsch., less frequently, Betula lutea Michx. Most often the fungus is encountered on living trees, but it may also grow on stumps, as demonstrated by the specimen found by Miss Suominen.

$P h$. albocrenulata has a conspicuous appearance 
and is easy to recognice. The fact that this fungus has, as far as is known, not been found before, in Finland or any of the Scandinavian countries and that in other parts of Europe only a few habitats are known, may thus be attributed to its actual rarity and its sporadic occurrence in Europe (cf. Pilát op.c.).

\section{LITERATURE CITED}

Christensen, C. M., 1955: Common Fleshy Fungi. Burgess Publishing Co., Minneapolis.

Kallio, P 1963: Zur Verbreitung einiger in Finnland südlichen Pilze, besonders in der südwestlichen Eichenzone. - Karstenia VI-VII, $35-74$.

Kauffman, C, H., 1918: The Agaricaceae of Michigan. - Ann. Rep. Mich. Geol. and Biol. Survey.

Lange, J. E., 1935: Flora Agaricina Danica I. Copenhagen.

Malmström, N., 1943: Agaricider, för landet nya o.a. från södra Finland. - Memor. Soc. F. F1. Fenn. 18, 77-83.

Mazelaitis, J., Gricius, A. \& Urbonas, V., 1965: Die neuen Funde der höheren Basidienpilze in der Litauischen Republik. - Problems of Mycology and Lichenelogy, 121-128.

Overholts, L. O., 1927: A Monograph of the Genus Pholiota in the United States. - Ann. Missouri Bot. Garden 14, 150.

Peck, C. H., 1907: New-York species of Pholiota. - N. Y. State Mus. Bull.

Pilát, A., 1936: Sur la récolte du Pholiota albocrenulata Peck, américain, dans les Carpathes. - Revue de Mycologie 1, 303-306.

Pouchet, A., 1935: Pholiota albocrenulata Peck. - Ann. Soc. Linn. Lyon, nouv. Sér. 78, 101 $-104$.

Schulmann, O. v., 1963: Zur Kenntnis der Basidiomyzeten Finnlands. - Karstenia VI-VII, 5 -34 . 